\title{
Urbanização e produção de condomínios horizontais fechados nas cidades de Capão da Canoa e Xangri-lá - RS: reflexos socioespaciais
}

\author{
Development and production of horizontal closed condominiums in Capão da Canoa and Xangri-lá cities - RS: \\ reflections sociospatial
}

\author{
Mariana Barbosa de Souza \\ Rogério Leandro Lima da Silveira \\ Universidade de Santa Cruz do Sul - UNISC - Santa Cruz do Sul - Rio Grande do Sul - Brasil
}

\begin{abstract}
Resumo: Analisam-se os processos de urbanização e desenvolvimento urbano dos municípios de Capão da Canoa e Xangri-Lá, na região do Litoral Norte do Rio Grande do Sul/Brasil, enquanto resultado do processo histórico de formação e organização do território, bem como das condições e contradições inerentes ao processo de reprodução do capital, e presentes nessas cidades. Uma das principais características do processo recente de urbanização dessas cidades é a produção de condomínios residenciais horizontais fechados e seus reflexos socioespaciais no desenvolvimento urbano local. A abordagem é qualitativa através da análise e interpretação do referencial teórico, dos dados obtidos com a pesquisa documental e através de entrevistas semiestruturadas junto aos principais agentes sociais envolvidos no processo de produção dos condomínios. São objetivos específicos: identificar a origem, as principais características e particularidades desse processo, bem como os principais agentes e suas estratégias na produção desses produtos imobiliários em ambas as cidades.
\end{abstract}

Palavras-chave: Urbanização. Condomínios residenciais fechados. Impactos ambientais. Reflexos socioespaciais. Litoral norte.

\begin{abstract}
Analyzes the processes of urbanization and urban development of the municipalities of Capão da Canoa and Shangri-La in the North Coast region of Rio Grande do Sul / Brazil, as a result of the historical process of formation and organization of the territory and the conditions and contradictions inherent in the capital of the reproduction process, and in those cities. A key feature of the recent urbanization of these cities is the production of closed horizontal condominiums and their socio-spatial and environmental impacts on local urban development. The qualitative approach is through the analysis and interpretation of the theoretical framework, the data obtained from the desk research and through semi-structured interviews with key social actors involved in the production of condominiums process. Specific objectives are to identify the source, the main characteristics and peculiarities of this process as well as the key players and their strategies in the production of these real estate products in both cities.
\end{abstract}

Keywords: Urbanization. Closed residential condominiums. Environmental impacts. Sociospatial reflections. North Coast. 


\section{Introdução}

A região do Litoral Norte do Rio Grande do Sul é delimitada ao sul pelo município de Balneário Pinhal, ao norte pelo Rio Mampituba, a leste pelo Oceano Atlântico e, a oeste, delimitada em função de sua formação geológica, relevo, bacia de drenagem e limites políticos, estendendo-se até os limites de São Francisco de Paula.

A região do Litoral Norte é formada pelas áreas totais ou parciais de 19 municípios, entre os quais se destacam Capão da Canoa e Xangri-Lá, onde o processo recente de urbanização tem sido intenso, notadamente através da produção de condomínios residenciais horizontais fechados. A produção desses novos produtos imobiliários tem sido acompanhada por significativos reflexos na organização socioespacial, através da consolidação do processo de segregação socioespacial, bem como pelos impactos ambientais, que tais produtos provocam, no ambiente natural característico dessa região do Estado.

O artigo, além dessa introdução, está estruturado em três tópicos. No primeiro aborda-se o processo de urbanização na região e nos municípios de Capão da Canoa e Xangri-Lá através de um breve resgate histórico desse processo, bem como da análise de dados demográficos secundários. No segundo tópico se analisa os condomínios residenciais horizontais fechados, identificando suas características, dinâmica de produção e os atores que nela participam, bem como suas estratégias de ação nas cidades. No terceiro e último tópico abordam-se alguns dos principais impactos ambientais e reflexos sócios espaciais desses novos produtos imobiliários, na organização espacial e desenvolvimento urbano das cidades de Capão da Canoa e Xangri-Lá. Por fim, realizam-se as considerações finais dessa reflexão.

\section{0 processo de urbanização do litoral norte e dos municípios de Capão da Canoa e Xangri-lá}

A ocupação inicial do Litoral Norte do Rio Grande do Sul deu-se devido a diversos condicionantes. Antes da década de 1940 não havia qualquer tipo de investimento estatal que facilitasse a ida do interior para o Litoral Norte gaúcho, o que fez com que a urbanização do Litoral Norte gaúcho ocorresse mais visivelmente a partir da década 1980.

Sobre a ocupação inicial da região do Litoral Norte do Rio Grande do Sul, de acordo com Strohaecker e Toldo Jr. (2013, p. 05):

A partir de 1732, a região começou a ser colonizada por imigrantes provenientes dos Açores, de Portugal e de Laguna, através da concessão de sesmarias e datas de terras. A economia da região baseava-se na agricultura, na pecuária e na pesca. As estâncias tinham suas sedes e principais atividades implantadas nas terras mais continentais, onde os recursos hídricos e o solo eram de melhor qualidade. As condições de alta salinidade e umidade, os ventos constantes, a vegetação rarefeita, o solo arenoso e os grandes campos de dunas, dificultavam o acesso e a utilização das terras adjacentes à orla, com exceção da foz dos rios Mampituba e Tramandaí, onde a atividade pesqueira apresentava certa relevância.

A urbanização do Litoral Norte do Rio Grande do Sul inicia a partir do pós-primeira guerra, ocasião em que os Municípios da região passaram a registrar um número maior de investimentos para fins turísticos, dentre eles destacam-se Capão da Canoa, Torres e Tramandaí, primeiramente pertencentes ao município de Osório. Entretanto, é a partir dos anos de 1930 que o processo de urbanização se torna uma realidade frente aos recursos investidos pelo Governo do Estado, na instalação e ampliação da rede de água e de energia elétrica.

Nesse período ainda poucas pessoas moravam em Capão da Canoa, conhecida como "Balneário", devido às suas qualidades para banho de mar. Primeiramente, as pessoas que passavam a temporada de veraneio no local, acreditavam que os banhos possuíam propriedades medicinais. Os banhos eram tomados às 5 horas da manhã e após não se podia tomar banho de água doce, para que as propriedades medicinais não perdessem seus efeitos. (SANTOS, 2005).

O processo de urbanização da região intensificou-se com a inauguração da autoestrada BR-290, em 1973, a qual serviu para que turistas 
provenientes das regiões de Porto Alegre e de Caxias do Sul fixassem residências de veraneio no Litoral Norte gaúcho.

Ainda, na década de 1980 foi construída a RS389, conhecida como Estrada do Mar, com a intenção de desafogar o trânsito na BR-101. A autoestrada liga os municípios entre Osório e Torres. A Estrada do Mar facilitou, ainda mais, o acesso ao Litoral do Norte do Rio Grande do Sul.

Com a maior acessibilidade ao litoral e aumento do fluxo de pessoas no período de veraneio, alguns loteamentos passaram a ser construídos na região e pequenos núcleos urbanos de comércio e serviços passaram a se constitui, estruturando, ainda que de modo precários novas praias. Tal processo, com o passar do tempo, acabou por promover diversas emancipações municipais na região.

Conforme dados da FAMURS (Federação das Associações de Municípios do Rio Grande do Sul) a maior parte das emancipações dos principais Municípios do Litoral Norte gaúcho ocorreu entre os anos de 1980 e 1996:

Quadro 1: Emancipações municipais na região do Litoral Norte - RS (1980 a 1996)

\begin{tabular}{|l|c|l|}
\hline $\begin{array}{l}\text { Novo } \\
\text { Município }\end{array}$ & $\begin{array}{r}\text { Ano da } \\
\text { emancipação }\end{array}$ & $\begin{array}{c}\text { Municíp } \\
\text { io de origem }\end{array}$ \\
\hline $\begin{array}{l}\text { Capão da } \\
\text { Canoa }\end{array}$ & 1982 & Osório \\
\hline Imbé & 1988 & Tramandaí \\
\hline Cidreira & 1988 & Tramandaí \\
\hline Arroio do Sal & 1988 & Torres \\
\hline Xangri-Lá & 1992 & Capão \\
\hline $\begin{array}{l}\text { Canoa } \\
\text { Pinhal }\end{array}$ & 1996 & Cidreira \\
\hline
\end{tabular}

Fonte: FAMURS, 2015.

As emancipações, somadas à melhoria do acesso rodoviário, aqueceram sobremaneira o mercado imobiliário, ampliando e intensificando as atividades nos setores da incorporação e comercialização imobiliárias e no da construção civil. Nesse contexto, as empresas de construção e as incorporadoras assumem o papel de principais atores produtores do espaço urbano local, os quais competiam por terras para fins de loteamentos.

A pressão efetuada pelos atores imobiliários exerceu influência direta sobre a legislação dos Municípios, os quais não conseguiram manter um padrão equilibrado de urbanização, nem tão pouco desenvolver de modo efetivo políticas de planejamento territorial que regulassem de modo eficaz e sustentável a expansão, a ocupação e o uso do solo urbano. Como exemplo, cita-se o caso de Capão da Canoa, em que a legislação vigente permite a construção de prédios de até 13 andares à Avenida Beira-Mar.

Nas duas últimas décadas a região do Litoral Norte tem apresentado um intenso aumento da sua população residente, e com ele um significativo processo de urbanização. O Gráfico 1, ilustra bem a dinâmica de crescimento da taxa de urbanização da região, nas décadas de 1990 e 2000:

Gráfico 1: Litoral Norte - RS: Taxa de urbanização 1991 a 2010

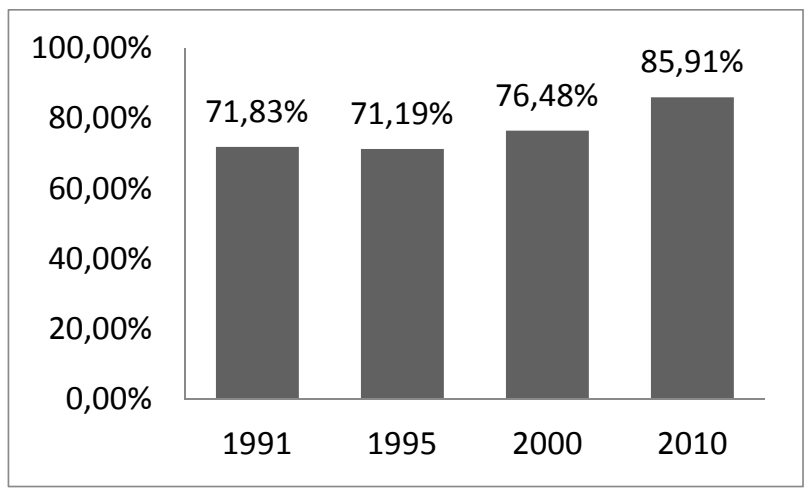

Fonte: FEE, 2015.

No que tange à questão de planejamento urbano, há que se considerar, contudo, os momentos distintos pelos quais passaram as cidades do Litoral Norte, especialmente em relação aos períodos que antecederam e sucederam as emancipações.

Nesse ponto, Strohaecker (2007, p. 162 - 163) ressalva que pode ser constatada, desde a década de 1940, uma preocupação por parte do Estado em regulamentar e fiscalizar o processo de urbanização 
do Litoral Norte do Rio Grande do Sul, objetivando a integração regional, a densificação demográfica e o crescimento econômico. Contudo, segundo a autora, a ocupação desordenada de determinados espaços do Litoral Norte, nas últimas décadas, decorre provavelmente da descentralização políticoadministrativa (com o processo emancipatório), da carência de fiscalização e da relativa omissão das instâncias de poder instituídas em garantir a preservação dos bens de uso público.

Vislumbra-se, portanto, que os processos de urbanização municipais também seguiram os contornos do modelo nacional, apresentando características comuns e reproduzindo os mesmos problemas vistos no processo de urbanização brasileiro, tanto na questão de segregação social quanto no rápido crescimento da cidade, na falta de planejamento e no direcionamento de diretrizes para o atendimento do mercado especulativo imobiliário.

\subsection{A urbanização e a produção do espaço urbano em Capão da Canoa e Xangri-lá}

A cidade de Capão da Canoa tem experimentado ao longo das últimas duas décadas um expressivo fluxo migratório, estimulado principalmente pela expansão do mercado imobiliário e pelo crescimento econômico, fatores que foram determinantes para sua estruturação urbana.

Em 2010, o município de Capão da Canoa apresentava uma população total de 42.040 habitantes, e o município de Xangri-Lá de 12.434 habitantes. Os municípios contribuíram para o crescimento da região.

Capão da Canoa e Xangri-Lá apresentam dinâmicas distintas, porquanto a população rural do primeiro cresceu junto com a população urbana. Em 1991 Capão da Canoa possuía 193 pessoas no meio rural, já no ano de 2010 esse número aumentou para 253 pessoas. No mesmo ritmo, a população urbana de Capão da Canoa aumentou nos últimos 20 anos.
Gráfico 2: Capão da Canoa - RS: População urbana e rural, 1991 a 2010

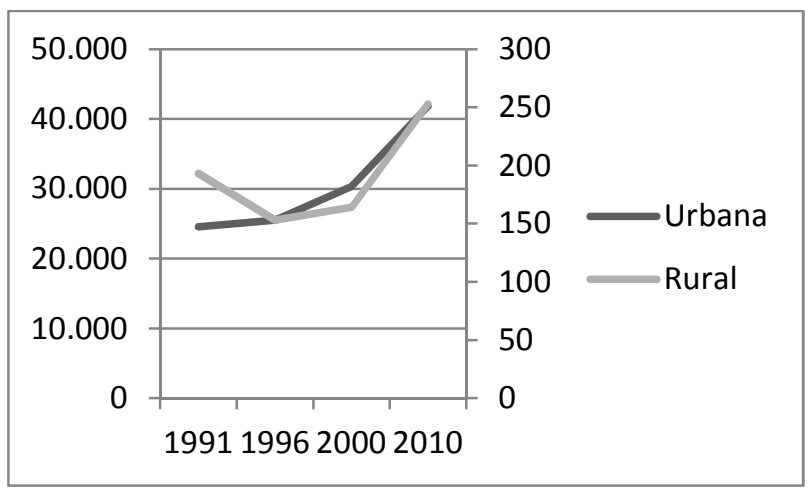

Fonte: FEE, 2015.

Enquanto que, em Xangri-Lá, a população rural só decaiu com os últimos anos: em 1996 a população rural do município era de 346 pessoas; em 2010 era de 55 pessoas. Um dos principais fatores responsáveis pela queda da população rural em Xangri-Lá é o surgimento de novos produtos imobiliários na região, mormente a instalação dos condomínios horizontais fechados, os quais foram construídos em áreas consideradas rurais do município.

Conforme se pode averiguar no Gráfico abaixo a população rural do município de Xangri-Lá reduziuse consideravelmente no período apresentado.

Gráfico 3: Xangri-Lá: População urbana e rural, 1996 a 2010

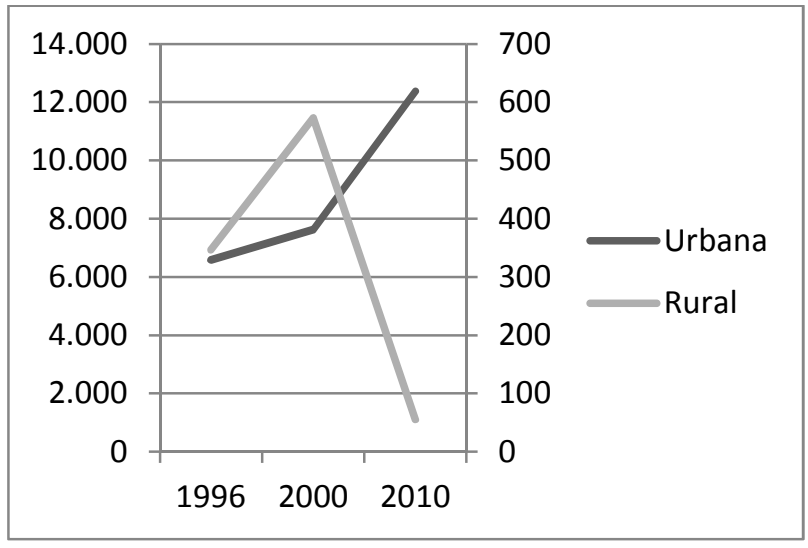

Fonte: FEE, 2015.

Fazendo uma comparação, a fim de se traçar um breve panorama do crescimento urbano na 
região, Capão da Canoa, em 1993 (portanto já com a emancipação de Xangri-Lá), detinha uma população total de 21.943 habitantes, enquanto que Xangri-Lá possuía 5.944 habitantes.

A taxa de urbanização de Capão da Canoa de 99,14\% em 1991 passou para 99,39\% em 2010. Na mesma direção a urbanização em Xangri-Lá passou de 95\% em 1996 para 99,55\% em 2010 (FEE, 2015).

Esse processo de migração e de fixação de contingente populacional, ocupando as áreas do município sem infraestrutura urbana, permanece considerável em períodos sazonais (veraneio e feriados prolongados). A princípio, contava com certa indiferença da sociedade e com o descaso do Poder Público, visto existirem grandes áreas desabitadas (em muitos casos, decorrentes da massa falida de loteadoras).

Assim, ainda que visto como algo a chamar a atenção da opinião pública, as ocupações irregulares ficaram relegadas a um plano secundário, colocandose como uma situação indefinida. Desse modo, embora fosse uma questão já percebida como problema social a exigir tratamento de ordem políticogovernamental, não recebia qualquer formulação ou encaminhamento de propostas para solucioná-la, sendo postergada pelo Poder Público.

A partir de 1995, houve o "boom" no setor imobiliário. E entre os anos de 1999 e 2002 o capital arrecadado dos imóveis construídos no período chegava a 1 bilhão e 488 milhões de reais. Este intenso crescimento do mercado imobiliário não se fez acompanhado da fiscalização do Poder Público. Pelos registros da Prefeitura de Capão da Canoa estavam "dependendo de habite-se 44 prédios, dos quais 31 com 13 pavimentos". (NEVES, 2004, p. 68).

O processo de configuração espacial da cidade de Capão da Canoa caracteriza-se por sucessivas expansões. Primeiramente, em direção ao sul, hoje bairro Girassol e, posteriormente, ao norte, hoje bairros Zona Nova, Zona Norte, Arco-Íris e Capão Novo.

Em razão do aumento populacional experimentado ao longo dos anos, acompanhado do crescimento desordenado e da ocupação irregular das áreas com finalidade urbana, os impactos se potencializaram e se refletiram sob várias formas e matizes no contexto local, pode-se citar a ocupação irregular de diversas áreas no município caponense. Desse modo, a questão veio tomando maiores proporções nos últimos tempos, até começar a dar sinais significativos de que sua continuidade seria prejudicial para os municípios.

A permanência do modelo começou a apresentar, com o passar dos anos, os aspectos indesejáveis de insustentabilidade. Do ponto de vista ambiental há degradação ambiental. Há também a precarização do trabalho por meio da informalidade (menos trabalhadores com carteira assinada), ilegalidade, e de alta exigência de serviços públicos, visto que cada vez mais o poder público é acionado para resolver determinadas questões, as quais vão desde educação, saúde, até regulamentação de uso do solo e relações entre particulares. Isto, consequentemente, levou os municípios a acumularem problemas e demandas que se desdobravam nas mais diversas áreas de atuação do Poder Público, aproximando o sistema público de serviços, a cada dia, a uma condição de colapso.

Fernandes (2004, p. 108) registra tais aspectos no processo de crescimento urbano da cidade de Capão da Canoa:

(...) Não se pode esquecer, obviamente, do aumento de vilas que cresceram na periferia da cidade, nas imediações da praia Arco-Íris, e em outros locais, onde se deu a ocupação desordenada, sem infra-estrutura adequada mediante a simples ocupação dos terrenos, sem qualquer respaldo legal e políticoadministrativo.

Outro aspecto a ser levantado em relação à postura governamental das municipalidades, no sentido de inibir a sua atuação de forma mais preventiva, diz respeito aos aspectos de incerteza e de desgaste político que poderiam surgir com a sua intervenção na realidade que estava se instalando. Ou seja, o receio em desconhecer os impactos e o custo político que poderiam advir com a sua atuação, podem ter contribuído para retardar o enfrentamento do problema e seu ingresso na agenda política. 
A combinação dessas resultantes reflete, assim, a ausência de intervenção do Poder Municipal em relação à questão, o qual, talvez por inércia, negligência ou mesmo conivência, nos últimos vinte anos, deixou de empregar qualquer ação maior quanto ao problema que começava a emergir.

Nesse contexto, sociedade e governo começam a perceber a gravidade e a complexidade do problema instalado, na medida em que esses fatores foram evoluindo. A questão assumiu outro enfoque e transformou-se em uma demanda recorrente, passando a exigir respostas dos Governos Municipais.

\section{A produção dos condomínios residenciais} horizontais fechados nas cidades de Capão da Canoa e Xangri-lá

No Brasil, os processos de produção do espaço urbano e de urbanização têm sido caracterizados por intensa e desigual valorização do solo urbano e consequente reestruturação urbana. Nas duas últimas décadas, sobretudo nas metrópoles, cidades médias, mas também em cidades turísticas junto ao litoral brasileiro, esse processo tem sido caracterizado pela crescente promoção de condomínios e loteamentos fechados, enquanto novos produtos imobiliários residenciais.

O aumento na demanda por condomínios fechados, por parte de segmentos da população com alta renda, tem contribuído com a nova dinâmica de produção e reprodução do espaço urbano, através da ampliação das áreas urbanizadas, mas também com o aumento da segregação espacial, da fragmentação urbana e da apropriação de espaços públicos, advinda do fechamento de loteamentos e da constituição de condomínios residenciais de lotes.

É preciso também destacar que, do ponto de vista jurídico, o instituto do condomínio horizontal residencial fechado é uma figura inexistente no país. Não existe no Brasil, legislação que trate da questão de forma específica. Assim, a fim de se preencher as lacunas existentes acerca do tema, outras leis esparsas, como os planos diretores municipais e o
Estatuto da Cidade (Lei 10.257/2001), são utilizadas, de modo precário e insuficiente, a fim de permitir e regular a instalação dos condomínios horizontais fechados ${ }^{1}$.

Os condomínios horizontais fechados são empreendimentos que têm por objetivo a criação de unidades autônomas, os chamados lotes, local nos quais serão ou não criadas construções, dependendo da intenção do seu proprietário.

No tocante à inexistência da figura do condomínio horizontal fechado, o Tribunal de Justiça do Rio Grande do Sul, vem proferindo nos últimos dez anos, decisões heterodoxas no sentido de regulamentar a situação, conforme a Apelação Cível n. ${ }^{\circ}$ 70.020.348.199, da 20a Câmara Cível, julgada em 21 de novembro de 2007, tendo como relator o Desembargador José Aquino Flôres de Camargo. A decisão referida contém a seguinte ementa:

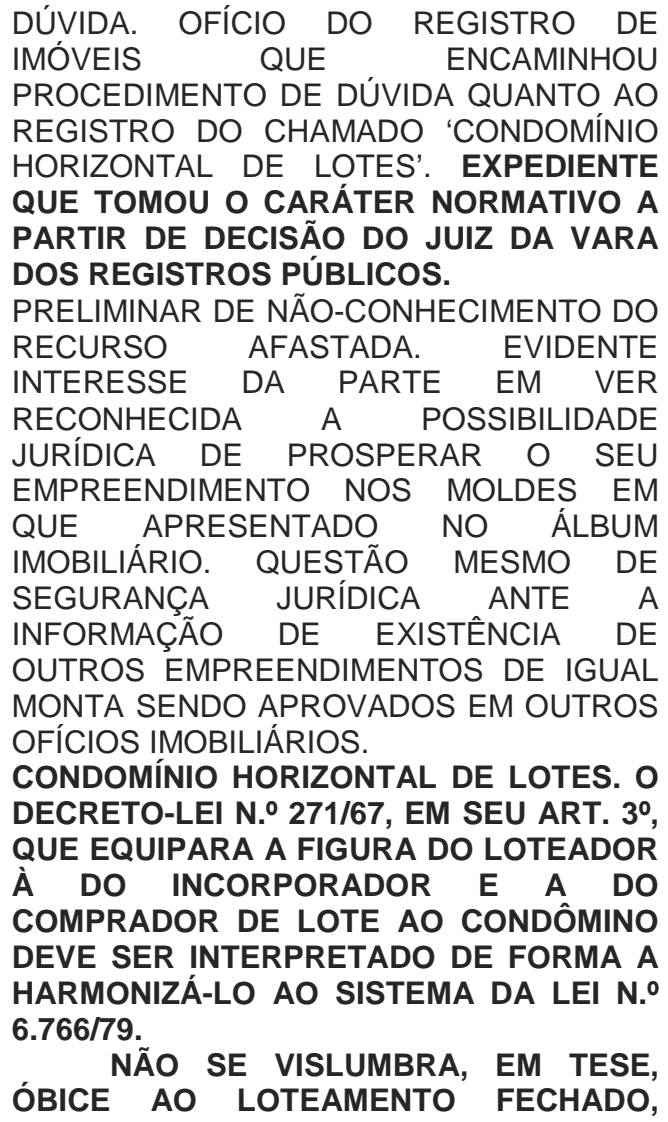

\footnotetext{
${ }^{1}$ Os condomínios horizontais fechados existentes na região no Litoral Norte, notadamente nos municípios de Capão da Canoa e de Xangri-Lá se caracterizam por serem todos murados e de alto padrão, ou seja, são casas residenciais de grande porte pertencentes ou destinados à população da classe $A$. Não existem em Capão da Canoa e Xangri-Lá condomínios horizontais com características diferentes das que foram mencionadas.
} 


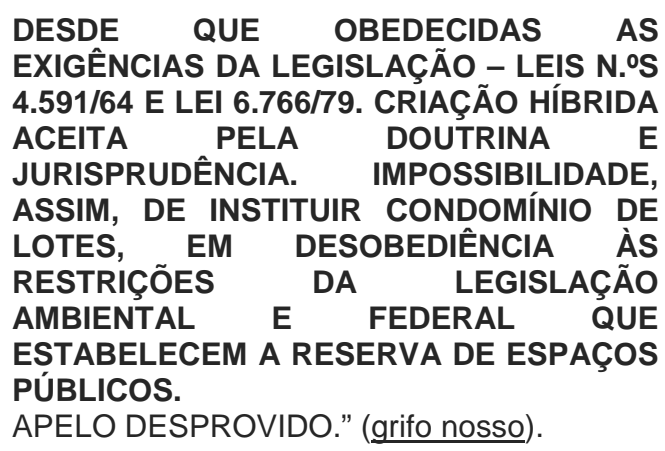

Na doutrina, na jurisprudência, bem como no cotidiano de quem trabalha em ações relativas aos condomínios fechados (corretores de imóveis, trabalhadores da construção civil, incorporadores e outros) encontrar-se-ão diversas nomenclaturas quanto à figura do condomínio horizontal fechado. $\mathrm{O}$ projeto de lei em tramitação no Congresso Federal relativo à Responsabilidade Territorial (Projeto de Lei

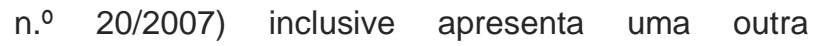
denominação a esse tipo de empreendimento: condomínio urbanístico, conforme art. 3ำ XII, do Projeto de Lei n.ำ 20/2007. Na região analisada no presente artigo, entende-se que a denominação mais adequada seja "condomínio horizontal fechado", mormente em razão das características apresentadas pelos mesmos.

Importante destacar que condomínios e loteamentos detém natureza jurídica diferente e inconfundível. Diversamente do condomínio, no loteamento não há copropriedade de áreas comuns. Ainda, no loteamento ocorre a divisão da gleba em lotes, com a devida abertura ou prolongamento de logradouros públicos. (REHBEIN e SOUZA, 2014).

Diversos municípios criaram leis complementares a fim de regularizar a matéria de acordo com as características de cada local. Neste sentido, importa mencionar que o município de Xangri-Lá foi pioneiro ao criar a primeira lei no Brasil que versa sobre condomínios horizontais fechados, servindo esta, de exemplo para municípios do país inteiro.

A crescente expansão urbana e transformação nos usos do solo, através da produção dos novos produtos imobiliários que são os condomínios residenciais fechados resultam do complexo processo de produção social do espaço urbano. Tal processo se dá historicamente, através das relações e contradições entre os agentes sociais que, conforme Corrêa (1989, p. 12), fazem e refazem a cidade. A saber: "(a) os proprietários dos meios de produção, sobretudo os grandes industriais; (b) os proprietários fundiários; (c) os promotores imobiliários; (d) o Estado; e (e) os grupos sociais excluídos".

Em Capão da Canoa e em Xangri-Lá, municípios expoentes da região, a maioria das grandes parcelas de terras é de proprietários individuais. Algumas são heranças de família e outras são de propriedades de alguns especuladores imobiliários que atuam na localidade. Percebe-se que os proprietários fundiários detêm interesse na expansão da cidade tendo em vista que o valor de troca dos espaços urbanos é maior do que o rural, logo há uma valorização de suas áreas.

Quanto aos promotores imobiliários pode-se afirmar que os incorporadores, quase na sua totalidade, não são da região e atuam em um mercado amplo (nacional e internacional). No mesmo sentido são as construtoras, as quais, em sua maioria, são de fora do Litoral Norte do Rio Grande do Sul. Entretanto, a mão de obra utilizada para construção dos condomínios horizontais fechados é caponense e xangrilense não havendo necessidade de buscar-se excedente fora dos municípios. Inclusive, diante da capacitação da mão de obra local, muitos construtores da capital Porto Alegre vêm buscar trabalhadores no Litoral Norte gaúcho.

Os atores que atuam na comercialização (Corretores de Imóveis) dos lotes dos condomínios fechados são de Capão da Canoa e de Xangri-Lá. Entretanto, há uma ampla divulgação deste tipo de empreendimento na capital e no interior do Rio Grande do Sul. Os planejadores de venda e profissionais de propaganda são vinculados a grandes agências de publicidades, porém, este tipo de serviço quase não é visto no Litoral Norte gaúcho. A estratégia de ação dos promotores imobiliários está vinculada diretamente a atender a demanda pela procura por residências de alto padrão, a qual está relacionada ao status dos condomínios, à segurança, e à infraestrutura oferecida. 
O Estado também atua, mormente, como regulador do uso e ocupação do espaço urbano e na formulação de leis vinculadas ao uso do solo. Ainda, ele demonstra sua atuação quando implanta serviços públicos, como malhas viárias e saneamento básico.

Existem também os grupos sociais excluídos, os quais segundo Corrêa (1989, p. 30), em terrenos públicos ou privados invadidos, "tornam-se, efetivamente, agentes modeladores do espaço urbano, produzindo seu próprio espaço, na maioria dos casos independentemente e a despeito de outros agentes”. Em Capão da Canoa e em Xangri-Lá estes grupos sociais são facilmente localizados. Em Capão da Canoa pode-se citar o bairro Novo Horizonte, o qual faz limite com o condomínio Condado de Capão da Canoa. Em Xangri-Lá o bairro Figueirinha ganha maior destaque, porquanto fica à margem da RS 389 (Estrada do Mar), enquanto que do outro lado da autoestrada localizam-se dois condomínios fechados de alto padrão: Atlântida Lagos Park e o Ilhas Park.

Os condomínios horizontais fechados são produzidos e aparecem na maioria dos municípios que compõem a região do Litoral Norte do Rio Grande do Sul. Entretanto, são mais comuns nas localidades de Capão da Canoa e de Xangri-Lá. Foi no município de Xangri-Lá que apareceram os primeiros condomínios fechados em meados da década de 1990. Na mesma época surgiram, também, na localidade de Capão da Canoa.

Entre os anos de 1990 e 2000 surgiram os seguintes condomínios fechados em Xangri-Lá: Xangri-Lá Villas Resort, Atlântida Lagos Park e Torres residenciais do Lagos Park, estes em Xangri-Lá. Enquanto que em Capão da Canoa surgia o Capão da Canoa Villas Resort.

A partir de então o fenômeno intensificou-se, sendo que em 2012 a construção civil direciona-se, principalmente, para a construção de residências em condomínios residenciais fechados. O condomínio Villas Resort começou a ser construído no ano de 1992, a partir de uma parceria entre a Prefeitura de Xangri-Lá, ocasião em que César Bassani era Prefeito e o empreendedor Elmar Ricardo Wagner (Diretor-Presidente do Grupo Capão Novo).
Em 2012 Capão da Canoa já detinha nove condomínios regularizados na Prefeitura e em XangriLá este número é ainda maior: são 18 condomínios fechados já construídos e outros nove em instalação.

FIGURA 2 - Localização dos condomínios em Xangri-Lá - 2012

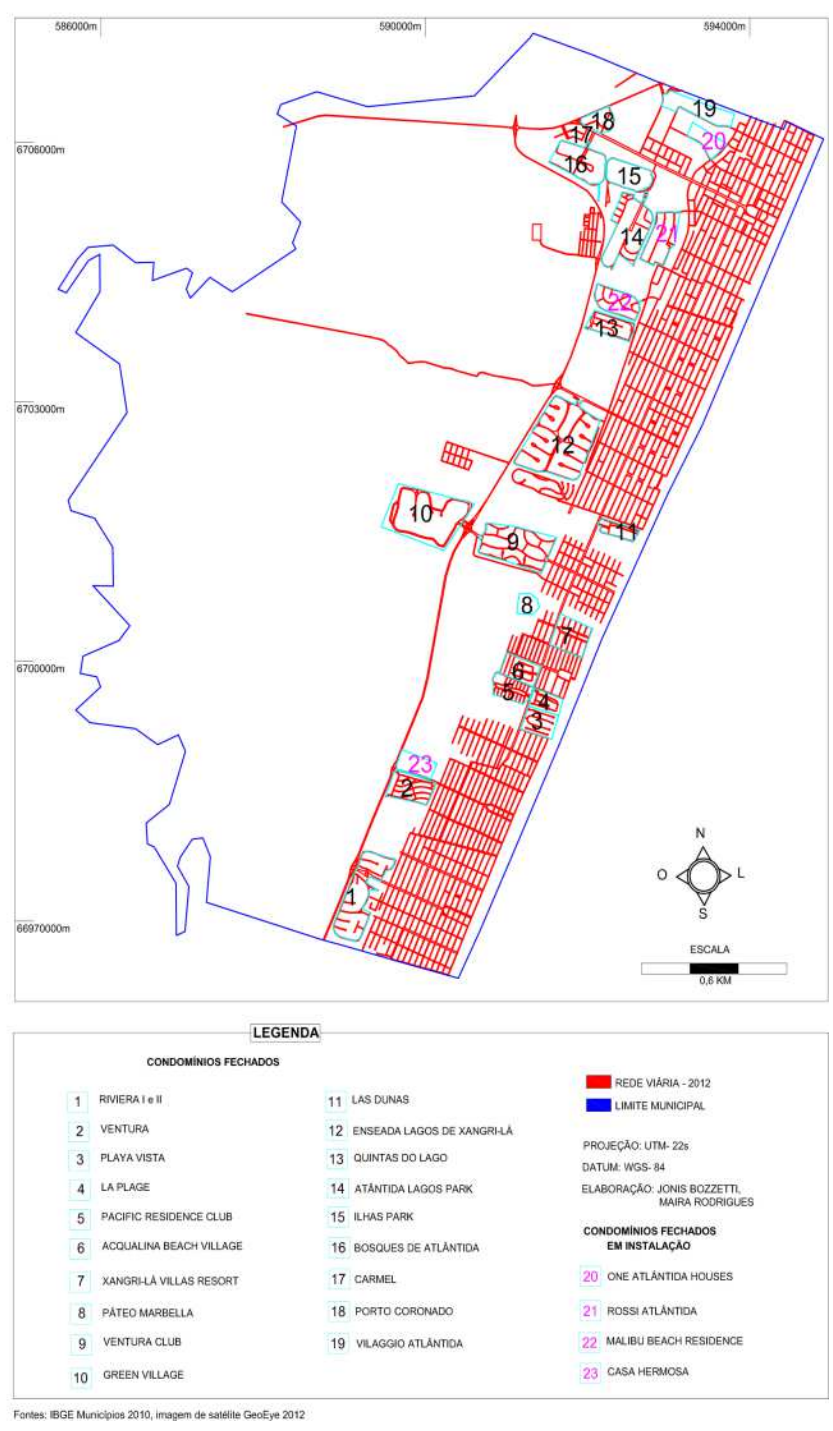


FIGURA 3 - Localização dos condomínios em Capão da Canoa - 2012

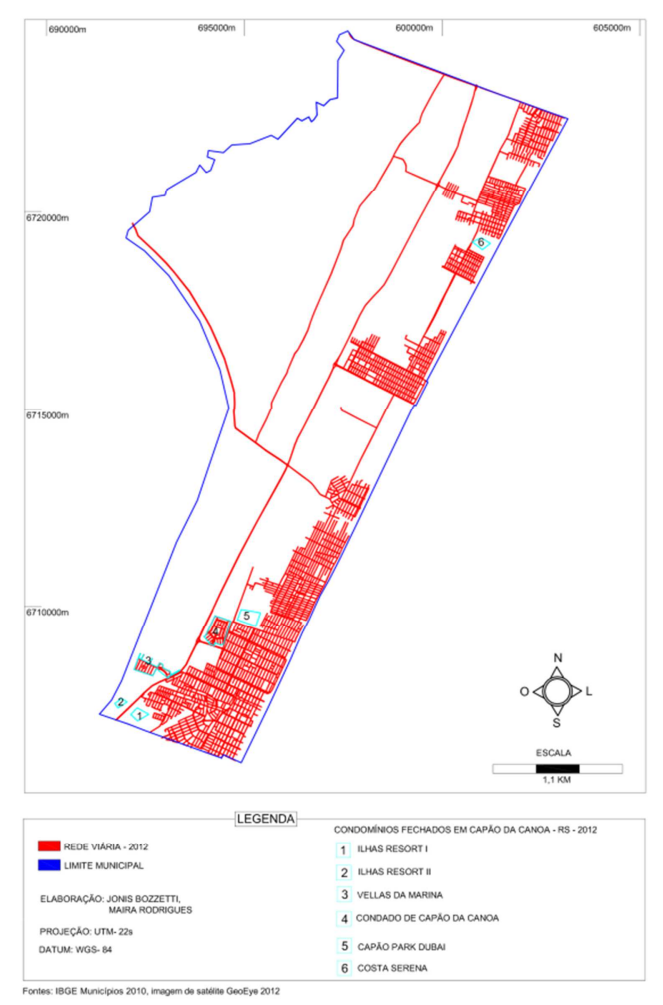

Os condomínios fechados não possuem uma localização pré-definida nas cidades. Eles estão localizados por toda a extensão territorial de Capão da Canoa e de Xangri-Lá, alguns estão à beira-mar e outros, como é o caso de Capão da Canoa à beira da Lagoa dos Quadros.

Com os condomínios fechados em ambas as localidades, faixas de terras que antes eram consideradas como rurais passaram a ter grandes instalações, com uma detalhada infraestrutura. Estas faixas de terra passaram a ser vendidas por um valor acima dos valores de mercado, ou seja, as áreas (às vezes distantes mais de $4 \mathrm{~km}$ do mar) passaram a agregar valor devido à grande demanda dos empreendedores que visam construir condomínios horizontais fechados.

A especulação imobiliária é a grande responsável pelo crescimento do mercado imobiliário da região, mormente após a emancipação de Capão da Canoa. Com a oscilação econômica existente na realidade brasileira, durante os anos de 1980 e 1990 muitas pessoas passaram a investir em imóveis, principalmente em terrenos; o mercado imobiliário acabou servindo com uma espécie de poupança, no caso do Litoral Norte gaúcho, de alto rendimento. A prática da especulação cresce cada vez mais na região e as pessoas, bem como investidores imobiliários investem em "terra" à espera que esta sofra valorização.

Importa salientar que há uma demanda da classe "A" pelas unidades residenciais em condomínios fechados pela questão do status social, da infraestrutura e da segurança.

Devido às potencialidades ambientais naturais existentes no local, o hectare localizado à margem da Lagoa dos Quadros vem sendo negociado no mercado imobiliário caponense por cerca de $\mathrm{R} \$$ 250.000,00 (Duzentos e cinquenta mil reais). Após a venda da gleba, cada lote é negociado por um valor distinto dependendo da sua localização dentro do empreendimento. No condomínio fechado Capão Ilhas Resort, os lotes variam entre $R \$ 100.000,00$ (cem mil reais) e $\mathrm{R} \$ 200.000,00$ (duzentos mil reais) cada um.

Neste outro condomínio, pode-se perceber que a tipologia das residências é distinta, cada uma sendo escolhida de acordo com o gosto do proprietário de cada lote.

É importante mencionar que todos os condomínios existentes à beira-mar de Xangri-Lá, no tocante à parte que é fronteiriça com a areia da praia, estes não são murados, ou seja, além de não possuírem muros também não privatizam de nenhuma forma o espaço público tocante à praia. Eles possuem apenas uma cerca, a qual contém um portão para facilitar o acesso dos moradores à praia, o que se pode verificar na seguinte imagem: 
Figura 3 - Condomínio La Plage - Xangri-Lá

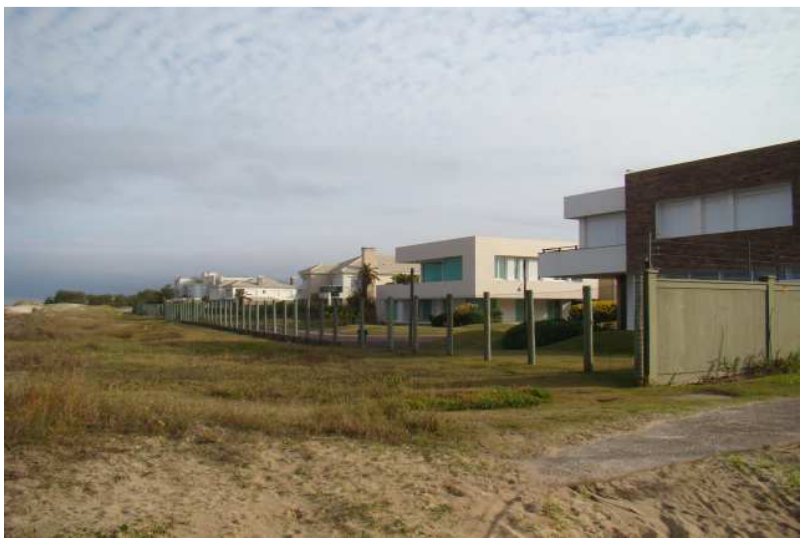

Fonte: Arquivo pessoal de Mariana Barbosa de Souza, 2012 (autoria da foto: Mariana B. de Souza).

Observando acima a Figura 2, pode-se perceber que os condomínios possuem residências de alto padrão. Estas são vendidas a preços altos no mercado (existem casas dentro dos condomínios avaliadas em mais de dez milhões de reais) e são direcionadas para o público exclusivo da classe "A". Diante disto houve uma ruptura social no tecido urbano, tanto de Capão da Canoa, quanto no de Xangri-Lá.

\section{Principais impactos ambientais e reflexos socioespaciais dos condomínios residenciais fechados no espaço urbano}

Nos últimos 20 anos, visualizou-se uma separação nítida entre os que possuem condições de adequar-se ao atual modelo econômico (e que residem em condomínios fechados ou possuem casas como segunda moradia) e os que estão excluídos deste processo por não possuírem as mesmas condições financeiras.

Nesse contexto, o Estado deixa de realizar investimentos em importantes áreas, passando a gerenciar apenas alguns serviços. Ele passa a atuar somente como um órgão regulador e provedor de bens e serviços básicos. Essa política vai gerar um efeito cascata, afetando os diferentes níveis sociais e, consequentemente, provocando o aumento da violência e da insegurança. (UEDA, 2006, p. 235).
O Estado não pode ser somente uma instituição reguladora. Ele deve estar disposto a criar políticas públicas que salvaguardem a cidade como um todo, a fim de evitar qualquer tipo de segregação, tanto espacial, quanto social, de acordo com o previsto no artigo 4.ำ do Estatuto da Cidade (Lei nº. 10.257 de 10 de julho de 2001).

Ainda, sobre o tema, a autora continua afirmando:

Muitos pesquisadores afirmam que a ineficiência das instituições públicas em garantir a segurança e proteger a população faz com que, as classes de maior poder aquisitivo se isolem em suas residências. Portanto, a expansão e consolidação dos loteamentos fechados evidenciam esse processo. As empresas do setor da construção civil e os agentes imobiliários vão construir estratégias de marketing e venda. Associam a tranquilidade, a qualidade de vida e o meio-ambiente com o caos urbano, aproveitando o contexto de desproteção e ineficácia do Estado. [...] Os loteamentos fechados aparecem como uma solução de moradia para os ganhadores, restando aos perdedores a exclusão (o outro lado do muro). (Grifou-se). (UEDA, 2006, p. 235).

Tamanha é a segregação causada pelos condomínios que muitas vezes os próprios moradores, excluídos deste tipo de moradia, acabam por não perceber que isto ocorre, muitas vezes eles são iludidos com algumas benfeitorias que os incorporadores realizam no entorno do condomínio para deixá-lo mais atrativo, como por exemplo, asfaltamentos de ruas e colocação de pórticos e projetos paisagísticos.

Assim, a periferia urbana, que era tratada como um espaço no qual o Estado mal conseguia gerir e oferecer serviços básicos, acabou se tornando um espaço de alta especulação no mercado imobiliário, um espaço apropriado para a construção de empreendimentos como os condomínios fechados, os quais são escolhidos por pessoas de alto poder aquisitivo para fixar suas residências, a fim de viver longe dos grandes centros urbanos.

A expansão da cidade feita com base nesse processo segregador, do ponto de vista social, e caótico, do ponto de vista urbano, teve 
como resultado a criação de um espaço claramente diferenciado e a exacerbação das marcas sociais. Atualmente esse padrão está consolidado e o próprio poder público tem de reconhecer os seus efeitos e se preocupar com eles. (CALDEIRA, 1984, p. 23).

$\mathrm{Na}$ medida em que os condomínios fechados se espalham pela malha urbana, mais aumenta a segregação que eles causam na cidade. Uma melhor distribuição de renda poderia oferecer para aqueles que não possuem, por algum motivo, acesso a todos os bens e serviços oferecidos pelo Estado.

Deve estar claro, também, que o poder sobre os recursos escassos da sociedade não pode ser determinado independentemente da acessibilidade aos recursos e ao seu preço. Os recursos podem ser exauridos, modificados, ou criados, de acordo com a natureza do recurso e sua manipulação. Assim há provavelmente diversas maneiras pelas quais a renda do indivíduo pode mudar. $\mathrm{O}$ indivíduo pode conseguir mais (menos), pode receber benefícios positivos (negativos) de uma troca no valor de sua propriedade, pode simplesmente ter mais (menos) recursos tornados úteis para ele a um baixo (alto) preço, ou pode ter qualquer combinação desses ganhos e perdas em um período particular. (HARVEY, 1980, p. 40).

As mazelas sociais geradas pela segregação são diversas e complexas e, muitas vezes, difíceis de serem identificadas, analisadas e resolvidas. A ação política e técnica da gestão municipal brasileira deve dispor de uma equipe interdisciplinar. É importante que haja um conjunto de ações produzidas a partir de uma análise interdisciplinar, a qual envolva sociólogos, planejadores urbanos, arquitetos, engenheiros, operadores jurídicos e etc. que estejam dispostos a unirem-se para tanto.

Ueda (2006, p. 235) afirma que "nos últimos anos, vários campos das Ciências Humanas e Sociais têm-se preocupado em discutir e analisar as novas periferias urbanas, aqui representadas pelos loteamentos fechados".

Muitas discussões acerca do tema vêm sendo travadas no meio acadêmico, dentre elas destacamse a (i)legalidade dos condomínios e a segregação socioespacial causada por estes.

Com a promulgação da Constituição da República Federativa do Brasil (05 de outubro de
1988) preocupações com o meio ambiente vieram à tona, mormente as questões inerentes aos bens transindividuais e difusos.

Ainda, de acordo com a FEPAM (2000, p. 09):

O Litoral Norte é uma região riquíssima sob o ponto de vista ambiental. Devido a sua idade geológica recente (cerca de 5.000 a.C.), seus ecossistemas são frágeis e raros. São poucas as regiões do planeta em que ocorrem praias retilíneas e contínuas de tamanha extensão. O Litoral gaúcho dispõe de $618 \mathrm{~km}$ de extensão. Esse processo geológico ainda em formação mostra uma sequência de ambientes de especial valor paisagístico e produtividade biológica. O cordão de lagoas, as barreiras de dunas, os banhados e os contrafortes da Serra Geral conferem a essa região um cenário diferenciado no continente latino-americano. Por outro lado, essas características não foram sempre valorizadas, nem consideradas durante o processo de ocupação. A urbanização inadequada vem trazendo, ao longo do tempo, prejuízos à população e ao ambiente.

$E$, levando em consideração que a região detém características peculiares únicas no mundo, a questão ambiental deve ser analisada. No mesmo sentido, a Constituição Estadual do Rio Grande do Sul (promulgada em 03 de outubro de 1989) prevê as diretrizes gerais da política ambiental, tendo inclusive, normas de punição aos causadores de poluição do dano ao meio ambiente. Entretanto, sua aplicação ainda é irrisória.

$\mathrm{Na}$ seara das leis ordinárias merece destaque a Lei de Crimes Ambientais (Lei n. -9.605 , de 12 de agosto de 1998), a qual dispõe sobre sanções penais e administrativas para pessoas físicas e jurídicas que pratiquem condutas lesivas ao meio ambiente.

O turismo no Litoral Norte, embora seja uma das principais fontes de renda da população prejudicou a fauna e a flora da região. Restam, apenas, resquícios de Mata Atlântica e as margens de lagoas, as dunas da beira-mar são os principais prejudicados, tendo em vista os recentes empreendimentos imobiliários construídos na área.

As normas de cunho ambiental são tão antigas quanto quaisquer outras normas sociais. Porém, pela análise de sua inserção no mundo jurídico, verifica-se que houve uma transformação da sua finalidade, do seu objetivo. A norma formal pode até ser a mesma, 
mas o paradigma ensejador da sua existência é diverso daqueles de antes. Enquanto as normas ambientais anteriores eram regidas com a finalidade de proteger-se e sustentar-se o recurso alimentar, hoje a questão do desenvolvimento econômico é que baliza o regramento ambiental (ALBERGARIA, 2005).

Ao versar sobre o panorama ambiental brasileiro, Leite (2003, p. 22-23), ensina:

\begin{abstract}
[...] a crise ambiental configura-se num esgotamento dos modelos de desenvolvimento econômico e industrial experimentados. De fato, o modelo proveniente da revolução industrial, que prometia o bem-estar para todos, não cumpriu aquilo que prometeu, pois, apesar dos benefícios tecnológicos, trouxe, principalmente, em seu bojo, a devastação ambiental planetária e indiscriminada. E que [...] o Estado de bem-estar marginalizou a questão social ambiental, pois, dirigido por políticas de pleno emprego e de maximização da utilização dos fatores de produção, ignorou e deixou de desenhar uma política ambiental com vistas à melhor qualidade de vida. Denote-se, também, que [...] a racionalidade econômica de curto prazo, é orientada para a acumulação de capital. E que [...] a defesa do meio ambiente e o crescimento econômico são vistos como inconciliáveis e excludentes.
\end{abstract}

A partir da Conferência de Estocolmo (1972), foi dado o primeiro grande passo internacional para, através de um congresso, estabelecer diretrizes ambientais. A questão que se sobrepunha naquele momento e que ainda hoje perdura, são dois pontos, aparentemente inconciliáveis: meio ambiente ecologicamente equilibrado e desenvolvimento.

No Brasil, com o advento da lei no. 6.938/81 que traçou a política nacional de meio ambiente, há um marco regulatório e disciplinador, que estabeleceu princípios, objetivos e instrumentos. Desta forma está inserida a avaliação ou estudo de impacto ambiental (EIA) exigida para empreendimentos de maior magnitude e que sabidamente trarão impacto ambiental na sua execução-princípio da precaução e da prevenção; na mesma linha, também instituiu um regime de responsabilização civil objetiva para o dano ambiental, conferindo ao Ministério Público legitimação para agir nesta matéria. (BRASIL - Lei da Ação Civil Pública, 1985).
Posteriormente, vem a Constituição Federal de 1988 que contemplou no capítulo VI do Título VIII, artigo 225 a proteção ambiental, um dispositivo moderno que coloca, tanto para o Poder Público, quanto para a coletividade o dever de proteger 0 ambiente para esta e para as futuras gerações. A Lei nํ. 6938/81 disciplinou a política e o sistema nacional do meio ambiente, constituindo-se no referencial ambiental mais importante juntamente com a Constituição Federal de 1988.

Em nível municipal, Capão da Canoa e XangriLá possuem Plano Diretor, legislação responsável pela fixação das diretrizes do desenvolvimento urbano de ambos os locais. Inclusive, Capão da Canoa detém em seu Plano Diretor determinação de criação de um inventário ambiental, a fim de catalogação das espécies da fauna e flora do Município para melhor protege-las o que ainda não aconteceu.

Visualiza-se que contornos políticos são efetuados na região, a fim de que os condomínios horizontais ultrapassem as barreiras legais existentes, dentre elas as imposições ambientais previstas em lei, mormente ante a fragilidade do ambiente em questão. Algumas ações já foram movidas na Justiça a fim de se proteger cômoros à beira mar, fauna e flora nas beiras de lagoas e, principalmente, acesso público a todos esses bens difusos.

Entretanto, a especulação imobiliária e o interesse das incorporadoras vêm agindo desenfreadamente nos últimos anos, contando com o suporte da municipalidade, ocasionando sérios danos ao meio ambiente, bem como a fragmentação da malha urbana dos municípios de Capão da Canoa e de Xangri-Lá e consequente segregação socioespacial.

\section{Considerações finais}

A análise do processo de urbanização e dinâmica do desenvolvimento do mercado imobiliário, sobretudo relacionada aos condomínios residenciais horizontais fechados, comprovou que a dinâmica territorial urbana do Litoral Norte do Rio Grande do 
Sul se caracteriza pela intensa urbanização e pelo aumento das desigualdades socioespaciais gerando ações e resultados produzidos pelos agentes sociais no espaço geográfico.

A ocupação desordenada da região deu-se, principalmente devido às emancipações, às migrações e às ações praticadas pelo Estado. Verificou-se durante a pesquisa que a decisão política para a aplicação ou não de certas medidas depende, mormente, de mudanças culturais. O engajamento do poder público, da sociedade civil organizada e de outras instituições é fator decisivo para a transformação do Litoral Norte do Estado do Rio Grande do Sul, principalmente no que tange ao desenvolvimento sustentável.

Pode-se verificar, também, que a diversidade ambiental é um importante fator para a construção identitária da região e um dos principais fatores que tem influenciado na localização e na valorização dos empreendimentos de luxo, os quais estão localizados nos cenários de alta beleza do litoral, quais sejam, beira mar e beiras de lagoas.

A partir da pesquisa realizada, concluiu-se que outros tipos de produtos imobiliários já estão sendo cogitados no mercado. O plano diretor de Capão da Canoa prevê que os muros dos condomínios fechados localizados na beira da Lagoa dos Quadros devem ser vazados para permitir a migração de espécies. Levando em consideração esta previsão legal, alguns empreendedores já mencionam um novo produto: um condomínio misto (aberto e fechado).

Pode-se perceber, também, que mesmo diante de uma legislação existente acerca da proteção ambiental, a inserção dos condomínios horizontais tem causado diversos impactos na realidade da região, os quais vão desde a destruição do ambiente natural (como a destruição dos cômoros à beira mar) e vedação de acesso público à beira da Lagoa dos Quadros, até a fragmentação da malha urbana e segregação socioespacial, tendo em vista que os empreendimentos são murados e detém a características de serem direcionados à classe $\mathrm{A}$.

Ainda, o judiciário vem se manifestando sobre a questão urbanística de forma dogmática, desconsiderando questões relevantes de ordem pública, como a segregação socioespacial, em prol do direito individual à segurança.

Ademais, uma agenda nova de pesquisa poderia vir a ser um estudo aprofundado de como a dinâmica imobiliária e a regulação dos usos do território através da produção de condomínios residenciais fechados, tem se efetivado nas cidades turísticas da região do Litoral Sul do Brasil.

\section{Referências}

ALBERGARIA, Bruno. Direito ambiental e a responsabilidade civil das empresas. Belo Horizonte: Fórum, 2005.

BRASIL. Lei n‥ 10.257 de 10 de julho de 2001 . Regula os artigos 182 e 183 da CF, estabelece diretrizes gerais da política urbana e dá outras providências. Diário Oficial [da] República Federativa do Brasil, Brasília, DF, 11 de julho de 2001. Disponível em: <http://www.planalto.gov.br/ccivil_03/leis//7347orig.ht m>. Acesso em: mai. 2015.

Lei n․ 4717 de 29 de junho de 1965. Regula a ação popular. Diário Oficial [da] República Federativa do Brasil, Brasília, DF, 5 de julho de 1965. Disponível em: <http://www.planalto.gov.br/ccivil_03/leis/l7347orig.ht m>. Acesso em: out. 2014.

Lei no. 6938, de 31 de agosto de 1981. Dispõe sobre a Política Nacional do Meio Ambiente, seus fins e mecanismos de formulação e aplicação, e dá outras providências. Diário Oficial [da] República Federativa do Brasil, Brasília, DF, 2 de setembro de 1981. Disponível em: <http://www.planalto.gov.br/ccivil_03/leis//7347orig.ht m>. Acesso em: mai. 2015.

Constituição (1988). Constituição da República Federativa do Brasil. Brasília, DF: Senado Federal, 1988.

Lei $n^{\circ}$. 9605, de 12 de fevereiro de 1998. Dispõe sobre as sanções penais e administrativas derivadas de condutas e atividades lesivas ao meio ambiente, e dá outras providências. Diário Oficial [da] República Federativa do Brasil, Brasília, DF, 13 de fevereiro de 1998. Disponível em: <http://www.planalto.gov.br/ccivil_03/leis/l7347orig.ht m>. Acesso em: mai. 2015.

CALDEIRA, Teresa Pires do Rio. A política dos outros: o cotidiano dos moradores da periferia e o que pensam do poder e dos poderosos. São Paulo: Brasiliense, 1984. 
CORRÊA, Roberto Lobato. O espaço urbano. São Paulo: Ed. Ática, 1989 e 1996.

DIRETRIZES AMBIENTAIS PARA O DESENVOLVIMENTO DOS MUNICÍPIOS DO LITORAL NORTE. FUNDAÇÃO ESTADUAL DE PROTEÇÃO AMBIENTAL - FEPAM. Cadernos de planejamento e gestão ambiental $-n . \stackrel{0}{1} .2000$

FEDERAÇÃO DAS ASSOCIAÇÕES DE MUNICÍPIOS DO RIO GRANDE DO SUL. FAMURS. Disponível em $<$ http://www.portalmunicipal.org.br/entidades/famurs/d ado geral/ufmain.asp?ildEnt=5523>. Acesso em: mai. 2015 .

FEE. Fundação de Economia e Estatística. Disponível em:

$<$ http://www.fee.tche.br/sitefee/pt/content/capa/index. php>. Acesso em: mai. de 2015.

FERNANDES, Jorge Luiz da Silva. A evolução histórico-geográfica de Capão da Canoa (1970-2004). In ESPÍNDOLA, L. A., FLORENTINHO, R. F., BARROSO, V. L. M. (orgs.). Raízes de Capão da Canoa. Porto Alegre: EST, 2004.

HARVEY, David. A justiça social e a cidade. São Paulo: Hucitec, 1980.

O enigma do capital e as crises do capitalismo. São Paulo: Boitempo, 2011.

LEITE, José Rubens Morato. Dano ambiental: do individual ao coletivo extrapatrimonial. 2. ed. São Paulo: Editora Revista dos Tribunais, 2003.

REHBEIN, Veridiana Maria; SOUZA, Mariana Barbosa de. A questão da legalidade dos novos produtos imobiliários na cidade de Santa Cruz do Sul. In: CAMPOS, Heleniza Ávila; SILVEIRA, Rogério Leandro Lima da. (Org.). Valorização do solo e reestruturação urbana: os novos produtos imobiliários na Região dos Vales - RS. Santa Cruz do Sul: Edunisc, 2014. p. 162-183.

RIO GRANDE DO SUL. Tribunal de Justiça. Apelação Cível n. 70.020.348.199, da 20a Câmara Cível. Relator: Des. José Aquino Flôres de Camargo. Porto Alegre, 21 de novembro de 2007. Disponível em: < http://www.tjrs.jus.br/site/>. Acesso em: 11 mai. 2015.

SANTOS, Mariza Simon dos. Origens de Capão da Canoa (1920-1950). Porto Alegre: EST, 2005.

SIRVINSKAS, Luís Paulo. Manual do Direito Ambiental. 4. ed. São Paulo: Saraiva, 2006.

STROHAECKER, Tânia Marques. A produção do espaço no Litoral Norte: uma análise preliminar. In: STROHAECKER, Tânia Marques; VERDUM Roberto (orgs.). Ensino de Geografia, Planejamento Ambiental e Gestão Territorial. Porto Alegre: Associação dos Geógrafos Brasileiros - Seção Porto Alegre, 2001.

A urbanização no Litoral Norte do Estado do Rio Grande do Sul: contribuição para a gestão urbana ambiental do município de Capão da Canoa. 2007. Tese (Doutorado em Geociências).Curso de Pós-Graduação em Geociências, UFRGS. Porto Alegre, 2 V. 2007. Disponível em: $<$ http://www.bibliotecadigitalufrgs.ufrgs.br> Acesso em: mai. 2015.

; TOLDO JR., Elírio E. A dinâmica territorial do Litoral Norte do Rio Grande do Sul. Apresentação oral: Sessão temática 3 - Redes de Cidades e Dinâmica Territorial, 2013.

UEDA, Vanda (org.). Dinâmica imobiliária e reestruturação urbana na América Latina. Santa Cruz do Sul: Edunisc, 2006. 